\title{
Combined Effect of Plantaricin BM-1 and Refrigeration Storage to Control Listeria Monocytogenes Inoculated in Brined Cooked Ham
}

\author{
Huimin Zhou, Yuanhong Xie, Hongxing Zhang, huixia Duan,Shan Shi, Yue Sun and Hui Liu \\ Beijing Laboratory of Food Quality and Safety, Beijing Key Laboratory of Agricultural Product Detection and Control of \\ Spoilage Organisms and Pesticide Residue \\ Department of Food Science Beijing University of Agriculture \\ Beijing, China \\ email:hxzhang511@163.com
}

\begin{abstract}
The effect of plantaricin BM-1 on the behavior of Listeria Monocytogenes in sliced brined cooked ham during refrigerated storage $\left(4^{\circ} \mathrm{C}\right.$ and $\left.9^{\circ} \mathrm{C}\right)$ was assessed. The combination of low storage temperature $\left(4^{\circ} \mathrm{C}\right)$ and plantaricin can significantly reduced viable counts of $L$. Monocytogenes during storage $(P<0.05)$. When the same amount of plantaricin was applied, the growth of $L$. Monocytogenes in brined cooked ham stored at $4{ }^{\circ} \mathrm{C}$ was significantly slower than that in sample stored at $9^{\circ} \mathrm{C}(\mathrm{P}<$ 0.01). Even combination of $1280 \mathrm{AU} / \mathrm{g}$ plantaricin and $4^{\circ} \mathrm{C}$ storage produced greater inhibition of $\mathrm{L}$. monocytogenes than combination of $5120 \mathrm{AU} / \mathrm{g}$ plantaricin and $9^{\circ} \mathrm{C}$. The combination of $4^{\circ} \mathrm{C}$ and $5120 \mathrm{AU} / \mathrm{g}$ plantaricin was the most effective treatment and can decrease the levels of $L$. monocytogenes 1.7 Log CFU/g at the end of storage.
\end{abstract}

Keywords-component; refrigerated storage; plantaricin; Listeria Monocytogenes; brined cooked ham

\section{INTRODUCTION}

Generally, ready-to-eat (RTE) meat products are free of pathogens after an adequate heat treatment during processing. However, they can easily be recontaminated by exposure to the environment during peeling, slicing, repackaging and other procedures $[1,2]$. L. Monocytogenes continues to be a major concern for food safety and its survival during the manufacture of brined cooked ham products is an important consideration $[3,4]$. Development of meat products with no added sodium nitrite could alter this sequence of hurdles and could have a negative effect on food safety. Therefore, the development of reduced salt meat products would require provide additional hurdles to pathogen growth in order to assure food safety and quality [5]. The application of bacteriocins as a preservation strategy has attracted increasing interest during recent years, as a result of the consumer demand for safe, fresh-tasting, RTE products with low levels of chemical preservatives during storage is the addition of natural antimicrobials as food ingredients [6,7]. Plantaricin BM-1 is produced by Lactobacillus plantarum BM-1, isolated from a traditionally fermented Chinese meat product. Plantaricin is very stable to heat and $\mathrm{pH}$. We have proved in vitro that its broad bactericidal activity affects most of the Gram-positive bacteria and some Gram-negative bacteria [8].

The previous study had not been assessed the effect of plantaricin and refrigerated storage against L. Monocytogenes in sliced brined cooked ham without chemical preservative. Therefore, the present study aimed to assess the effects of plantaricin and storage temperature on the behavior of L. Monocytogenes on brined cooked ham during shelf life.

\section{MATERIALS AND METHODS}

\section{A. Bacterial Strains and Culture Conditions}

Lactobacillus plantarum BM-1, the bacteriocin producer strain was isolated from a traditionally fermented Chinese meat product [8]. The strain was cultured in MRS at $37^{\circ} \mathrm{C}$ for $24 \mathrm{~h}$ and subcultured twice ( $2 \%$ inoculum). $L$. monocytogenes ATCC 54003 was used as a bacteriocin-sensitive strain to determine the inhibitory activity of plantaricin BM-1 preparations. Two consecutive pre-cultures in brain heart infusion (BHI, AoBoXing Company, Beijing, China) of $6 \mathrm{~h}$ and $12 \mathrm{~h}$, respectively.

\section{B. Preparation of Plantaricin BM-1}

$3 \mathrm{~L}$ sterile MRS broth was inoculated with $2 \%(\mathrm{~V} / \mathrm{V})$ of L. plantarum BM-1 and incubated at $37^{\circ} \mathrm{C}$. According to the method of Zhang et al. [8], partially purified plantaricin BM-1 was obtained. Before used, freeze-dried eluted fractions were dissolved in 1:40 of the initial culture volume in phosphate buffer $(50 \mathrm{mM}, \mathrm{pH} 6.5)$ and sterilized by filtration through a $0.22 \mathrm{um}$ pore size Millex GP filter. 


\section{Assay for Bacteriocin Activity}

Bacteriocin activity was determined by agar well diffusion method using stainless steel cylinders of $8 \mathrm{~mm}$ (outer) diameter and the bacteriocin-sensitive L. monocytogenes ATCC 54003 was used as the indicator strain. The extract titer was expressed in arbitrary units per $\mathrm{ml}(\mathrm{AU} / \mathrm{ml})$. An arbitrary unit (AU) was defined as the highest dilution showing growth inhibition of the indicator lawn, and bacteriocin activity was expressed as AU/ml [9].

\section{Brined Cooked Ham Manufacturing}

Brined cooked ham was prepared with lean pork shoulder and the following additives $(\mathrm{g} / \mathrm{Kg})$ water, 200; sodium chloride, 26; dextrose, 0.6; sodium tripolyphosphate, 1.3; sodium hexametaphosphate, 1.3; sodium pyrophosphate, 1.3; sodium ascorbate, 0.35; sucrose, 10; potato starch, 30; soy protein isolated, 25. Pork shoulder meat bought from supermarket was minced in a cutter to a particle size of 3-4 $\mathrm{mm}$ and brined. Also, all the ingredients were homogenized in a mixer grinder for $30 \mathrm{~min}$. The mixture was stuffed into $90 \mathrm{~mm}$-diameter synthetic plastic casings and cooked by steam at $75^{\circ} \mathrm{C}$ for $2 \mathrm{~h}$. Whole pieces of brined cooked ham were cooled at $1{ }^{\circ} \mathrm{C}$ for $12 \mathrm{~h}$ in a refrigerator and then aseptically sliced into 3-4 mm thick slices (approximately $25 \mathrm{~g} /$ slice).

\section{E. Sample Preparation and Refrigerated Storage}

Four independent lots were prepared: a control without plantaricin, three lots containing 1280, 2560, $5120 \mathrm{AU} / \mathrm{g}$ of plantaricin BM-1. Plantaricin preparation were added into meat paste to accordingly obtain three lots containing 1280, 2560, $5120 \mathrm{AU} / \mathrm{g}$ of plantaricin; Sliced brined cooked hams were inoculated with $10^{4} \mathrm{CFU} / \mathrm{g}$ of $L$. monocytogenes. Afterwards, all brined cooked hams were vacuum-packaged with a packer in polyamide-polyethylene bags and stored at $4{ }^{\circ} \mathrm{Cor} 9{ }^{\circ} \mathrm{C}$, respectively.

\section{F. Enumeration of L. monocytogenes}

Samples from each treatment were extracted in triplicate at selected times to determine viable counts of $L$. Monocytogenes. $25 \mathrm{~g}$ ham were aseptically sampled and mixed $(1: 10)$ with dilution medium $(0.1 \%$ peptone, $0.85 \%$ $\mathrm{NaCl}$ ). Homogenisation was done in a stomacher for $2 \mathrm{~min}$. After appropriate dilutions, enumeration of $L$. Monocytogenes performed by spread plating on PALCAM agar incubated at $37^{\circ} \mathrm{C}$ for $48 \mathrm{~h}$. The detection limit of the above techniques was $10 \mathrm{CFU} / \mathrm{g}$. All microbial counts were expressed as $\lg (\mathrm{CFU} / \mathrm{g})$.

\section{G. Measurements of $\mathrm{pH}$}

The $\mathrm{pH}$ values were determined by homogenizing $10 \mathrm{~g}$ of ham sample in $90 \mathrm{~mL}$ distilled water (pH 7.0), with PHSJ - 5 Shanghai ray magnetic $\mathrm{pH}$ meter a Crison Basic $20 \mathrm{pH}$-meter.

\section{H. Statistical Analyses}

Statistical analyses was performed using the Analysis of Variance procedure of SAS Proprietary Software, version 9.0 (SAS Institute Inc., Cary, NC, USA.). Means was used to compare differences between treatments. The model included lot, storage temperature, storage time, and their interaction as fixed effects. Differences between effects were assessed by the Bonferroni t-test $(\mathrm{P}<0.05)$.

\section{RESULTS AND ANALYSIS}

\section{A. Effect of Plantaricin BM-1 Combined with}

Refrigerated Storage on the L. monocytogenes Inoculated in Brined Cooked Ham

Refrigeration of sliced brined cooked ham at $4^{\circ} \mathrm{C}$ allowed the growth of $L$. Monocytogenes in control lot from inoculated levels (4.07 Log CFU/g) to a value of 8.45 $\log \mathrm{CFU} / \mathrm{g}$ at day 21 of storage (Fig. 1A). By contrast, refrigeration of ham at $9^{\circ} \mathrm{C}$ allowed the growth of $L$. Monocytogenes in control lot from inoculated levels (4.07 $\log \mathrm{CFU} / \mathrm{g}$ ) to a value of $8.91 \mathrm{log} \mathrm{CFU} / \mathrm{g}$ at day 6 of storage (Fig. 1B). Thus, refrigeration at the low temperature proved to have a bacteriostatic effect against $L$. monocytogenes. However, it is unrealistic to maintaining $4^{\circ} \mathrm{C}$ throughout the distribution chain. This suggests the need to apply bacteriocins to chilled storage to prevent $L$. Monocytogenes growth.

Plantaricin BM-1 application significantly reduced the growth of L. Monocytogenes $(\mathrm{P}<0.05)$ compared with control in brined cooked ham stored at $4{ }^{\circ} \mathrm{C}$ (Fig. 1A). The treatment with $5120 \mathrm{AU} / \mathrm{g}$ plantaricin was the most effective to control L. monocytogenes . L. monocytogenes counts in sample treated with $5120 \mathrm{AU} / \mathrm{g}$ plantaricin keep reducing from initial inoculums to $1.81 \mathrm{log} \mathrm{CFU} / \mathrm{g}$ on day 21. Afterwards, L. monocytogenes were able to regrow, but viable counts for the samples were significantly lower $(\mathrm{P}<0.05)$ than the control at the end of storage (Fig. 1A).

$1280 \mathrm{AU} / \mathrm{g}$ plantaricin added to ham stored at $9{ }^{\circ} \mathrm{C}$ were not significantly effective in preventing the $L$. monocytogenes growth (Fig. 1B). 2560, $5120 \mathrm{AU} / \mathrm{g}$ of plantaricin BM-1 added to ham stored at $9{ }^{\circ} \mathrm{C}$ could significantly slow $\operatorname{down}(\mathrm{P}<0.05)$ the breeding of $L$. monocytogenes compared to the control during whole storage period. Compared with the control, the greatest reduction of $L$. monocytogenes was observed in lot with $5120 \mathrm{AU} / \mathrm{g}$ of plantaricin.

When the same amount of plantaricin was applied, the growth of $L$. Monocytogenes in samples stored at $4{ }^{\circ} \mathrm{C}$ was significantly slower than that in sample stored at $9{ }^{\circ} \mathrm{C}(\mathrm{P}<$ $0.01)$. Even the $1280 \mathrm{AU} / \mathrm{g}$ plantaricin and $4^{\circ} \mathrm{C}$ storage produced greater inhibition of $L$. monocytogenes than the $5120 \mathrm{AU} / \mathrm{g}$ plantaricin and $4^{\circ} \mathrm{C}$ treatment A1280 (Fig. 1).

\section{B. $p H$ Evolution}

As shown in Fig.2, the $\mathrm{pH}$ values showed a rapid decrease from day 7 to day 14 in control samples, and remained stable in the further storage. Plantaricin BM-1 application significantly inhibited the decline of $\mathrm{pH}$ value compared with the control during whole storage $(\mathrm{p}<0.05)$. For the samples added with 5120 AU/g plantaricin BM-1, a dramatic decrease $(\mathrm{P}<0.05)$. 


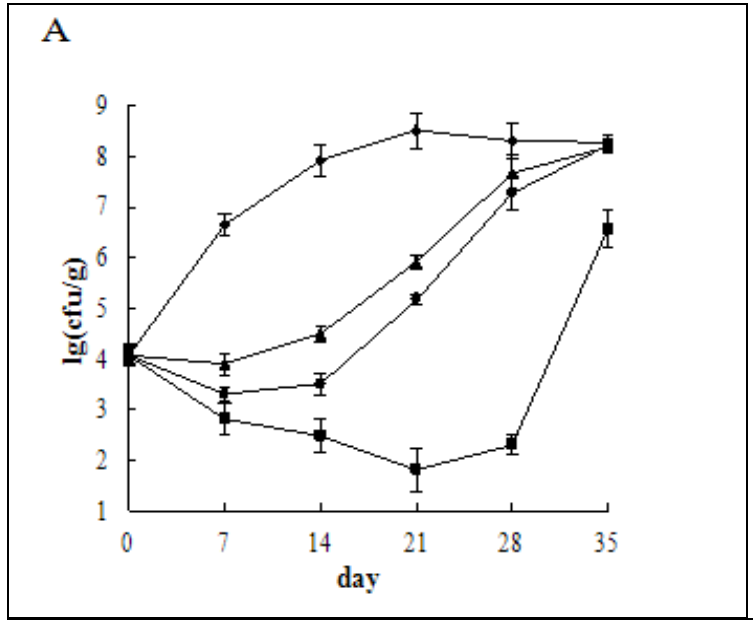

B

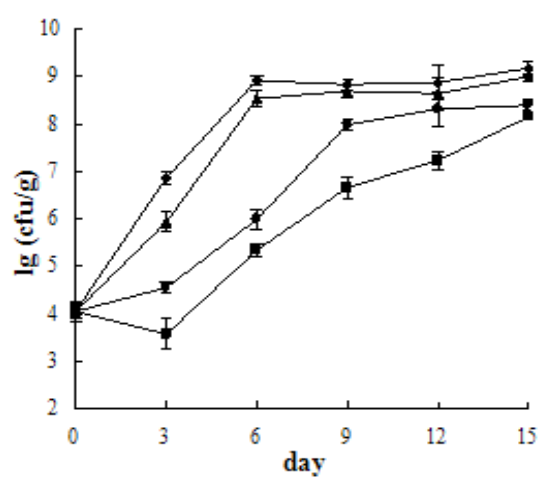

Figure 1. Evolution of L. monocytogenes (A, B) by plantaricin BM-1 at different concentrations in packaged sliced brined cooked ham without chemical preservative stored at $4{ }^{\circ} \mathrm{Cor} 9{ }^{\circ} \mathrm{C}$. Control without plantaricin BM-1 $(\diamond)$; Brined cooked ham treated with $1280 \mathrm{AU} / \mathrm{g}$ Plantaricin BM-1 (ム); Brined cooked ham treated with $2560 \mathrm{AU} / \mathrm{g}$ Plantaricin BM-1 (•); Brined cooked ham treated with $5120 \mathrm{AU} / \mathrm{g}$ Plantaricin BM-1 (-); Values are the average \pm SD (error bars) of three individual packages of two independent experiments.

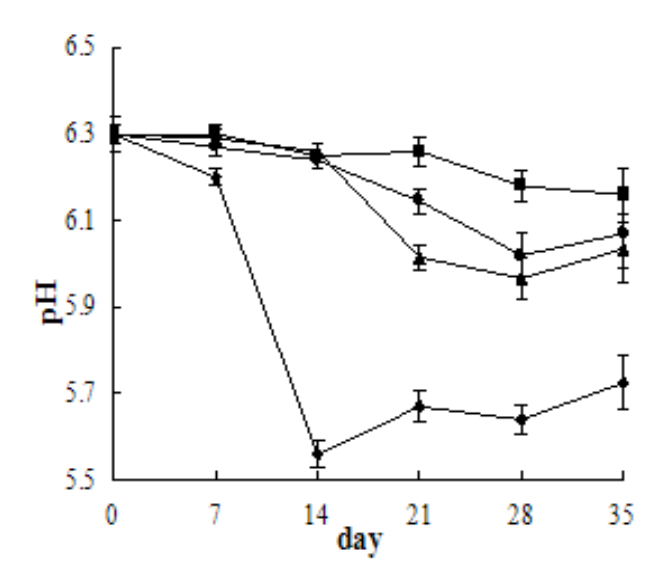

Figure 2. Evolution of $\mathrm{pH}$ by plantaricin BM-1 at different concentrations in packaged sliced brined cooked ham without chemical preservative stored at $4{ }^{\circ} \mathrm{C}$. Control without plantaricin BM-1 $(\bullet)$; Brined cooked ham treated with $1280 \mathrm{AU} / \mathrm{g}$ Plantaricin BM-1 (4); Brined cooked ham treated with $2560 \mathrm{AU} / \mathrm{g}$ Plantaricin BM-1 (•); Brined cooked ham treated with 5120 AU/g Plantaricin BM-1 ((); Values are the average \pm SD (error bars) of three individual packages of two independent experiments.

\section{DISCUSSION}

Although L. Monocytogenes is able to grow during refrigerated storage, temperature control has proved to be essential in reducing the risk of the pathogen. At $4^{\circ} \mathrm{Cthe}$ growth of $L$. Monocytogenes was slower than at $9{ }^{\circ} \mathrm{C}$ and the counts were between 1.54 and $4 \mathrm{Log} \mathrm{CFU} / \mathrm{g}$ lower than at $6^{\circ} \mathrm{C}$ on day 15 . Thus, refrigeration at the low temperature proved to have a bacteriostatic effect against $L$. monocytogenes. A similar observation has been made by Anna Jofre et al [10], who reported that at $1^{\circ} \mathrm{C}$ the growth of $L$. Monocytogenes was slower than at $6^{\circ} \mathrm{C}$ and the counts reached by the end of storage were between 1.4 and 7.2 Log CFU/g lower than at $6^{\circ} \mathrm{C}$. When the same amount of plantaricin was applied, the growth of $L$. Monocytogenes in samples stored at $4{ }^{\circ} \mathrm{C}$ was significantly slower than that in sample stored at $9{ }^{\circ} \mathrm{C}(\mathrm{P}<0.01)$. $5120 \mathrm{AU} / \mathrm{g}$ plantaricin applied as an additional hurdle to refrigeration temperature $\left(4^{\circ} \mathrm{C}\right)$ was effective for controlling $L$. monocytogenes at the end of storage, which $1.7 \log \mathrm{CFU} / \mathrm{g}$ lower than control.

\section{CONCLUSIONS}

In conclusion, the results presented here show that addition of plantaricin BM-1 in the formulation of brined cooked ham and storage at $4^{\circ}$ Cprovides an effective protection against L. monocytogenes. Especially, The combination of $4{ }^{\circ} \mathrm{C}$ and $5120 \mathrm{AU} / \mathrm{g}$ plantaricin was the most effective treatment to control and can decrease the levels of L. monocytogenes $1.7 \mathrm{Log} \mathrm{CFU} / \mathrm{g}$ at the end of storage.

\section{ACKNOWLEDGEMENTS}

The research was financially supported by National Program Grant from the Ministry of Science and Technology of the People's Republic of China (No.SS2012AA101606-05), the Importation and Development of High-Caliber talents project of Beijing Municipal Institutions (CIT\&TCD20140315).

\section{REFERENCE}

[1] Gombas D.E., Chen Y. and Clavero R.S. Survey of Listeria Monocytogenes in ready-to-eat foods[J]. Journal of Food Protection, 66(4), pp. 559-569, 2003.

[2] Reij M.W., and Den Aantrekker. E.D. Recontamination as a source of pathogens in processed foods[J]. International Journal of Food Microbiology, 91(1), pp.1-11, 2004.

[3] Martin, B., Garriga, M., \& Aymerich, T. Prevalence of Salmonellas pp. and Listeria Monocytogenes at small-scale Spanish factories producing traditional fermented sausages. Journal of Food Protection, 74(5), pp.812-815, 2011.

[4]Tompkin, R. B. Control of Listeria Monocytogenes in the food-processing environment. Journal of Food Protection, 65, pp.709-725, 2002

[5] Doyle, M.E., \& Glass, K. A. Sodium reduction and its effect on food safety, food quality, and human health. Comprehensive Reviews in Food Science and Food Safety, 9, pp.44-56, 2010.

[6] Gálvez, A., Abriouel, H., López, R.L., Omar, N.B., Bacteriocin-based strategies for food biopreservation. Int. J. Food Microbiol. 120, pp. 51-70, 2007.

[7] Samir Ananou, Margarita Garriga, Anna Jofré, Teresa Aymerich, Antonio Gálvez, Mercedes Maqueda Combined effect of enterocin AS-48 and high hydrostatic pressure to control food-borne pathogens inoculated in low acid fermented sausages. Meat Sci. 84 pp.594-600, 2010 
[8] Zhang, H., L. Liu, Y. Hao, S. Zhong, H. Liu, T. Han, and Y. Xie. Isolation and partial characterization of a bacteriocin produced by Lactobacillus plantarum BM-1 isolated from a traditionally fermented Chinese meat product. Microbiol. and immunol. 57, pp.746-755, 2013

[9] Kwaadsteniet M.D., T. Fraser, C.A. Van Reenen, and L.M. Dicks. Bacteriocin T8, a novel class IIa sec-dependent bacteriocin produced by Enterococcus faecium T8, isolated from vaginal secretions of children infected with human immunodeficiency virus. Appl. Environ. Microbiol. 72, pp.4761-4766, 2006.

[10] Jofré A, Martin B, Garriga M, et al. Simultaneous detection of Listeria monocytogenes and Salmonella by multiplex PCR in cooked ham[J]. Food microbiology, 22(1), pp.109-115, 2005. 